\title{
First record of the water flea Coronatella (Ephemeralona) elegans (Kurz, 1875) (Cladocera: Anomopoda) in Russia
}

\author{
Первая находка ветвистоусого ракообразного Coronatella \\ (Ephemeralona) elegans (Kurz, 1875) (Cladocera: Anomopoda) \\ в России
}

\author{
Petr G. Garibian ${ }^{1}$, Mariia D. Alksenova ${ }^{1,2}$, Artem Yu. Sinev ${ }^{3^{*}}$ \\ П.Г. Гарибян ${ }^{1}$, М.А. Аксенова ${ }^{1,2}$, А.Ю. Синев ${ }^{3^{*}}$
}

\footnotetext{
${ }^{1}$ A.N. Severtsov Institute of Ecology and Evolution, Leninsky Prospect 33, Moscow 119071, Russia.

${ }^{1}$ Институт проблем экологии и эволюции им. А.Н. Северцова РАН, Ленинский проспект, д. 33, Москва 119071, Россия.

${ }^{2}$ Department of Hydrobiology, Biological Faculty, M.V. Lomonosov Moscow State University, Leninskie Gory, Moscow 119234, Russia.

${ }^{2}$ Кафедра гидробиологии, Биологический факультет, Московский государственный университет им. М.В. Ломоносова, Ленинские горы, Москва 119234, Россия.

${ }^{3}$ Department of Invertebrate Zoology, Biological Faculty, M.V. Lomonosov Moscow State University, Leninskie Gory, Moscow 119234 , Russia.

${ }^{3}$ Кафедра зоологии беспозвоночных, Биологический факультет, Московский государственный университет им. М.В. Ломоносова, Ленинские горы, Москва 119234, Россия.

* Corresponding author: artemsinev@yandex.ru
}

KEY WORDS: Cladocera, Coronatella, first record, morphology, faunistics, Russia, Kalmykia. КЛЮЧЕВЫЕ СЛОВА: Cladocera, Coronatella, новая находка, морфология, Россия, Калмыкия.

ABSTRACT: Coronatella (Ephemeralona) elegans (Kurz, 1875), previously known from temporary waters of Central Europe and the Mediterranean is found for the first time in Russia, on the Taman' Penninsula and in the Republic of Kalmykia, at a distance of about 1400 and $2000 \mathrm{~km}$ respectively from its easternmost locality in Europe. Morphology of parthenogenetic females, ephippial females and males of the found population is studied. Our data show the importance of sampling of temporary waterbodies for full evaluation of local Cladocera fauna.

How to cite this paper: Garibian P.G., Aksenova M.D., Sinev A.Yu. 2021. First record of the water flea Coronatella (Ephemeralona) elegans (Kurz, 1875) (Cladocera: Anomopoda) in Russia // Arthropoda Selecta. Vol.30. No.1. P.34-38. doi: 10.15298/arthsel. 30.1.03

РЕЗЮМЕ. Ветвистоусый рак Coronatella (Ephemeralona) elegans (Kurz, 1875), ранее известный из временных водоемов Центральной Европы и Средиземноморья, впервые обнаружен в России, на Таманском полуострове и в Республике Калмыкия, на расстояниях около 1400 и 2000 км соответственно от его наиболее восточного местообитания в Европе. Исследована морфология партеногенетических и эфиппиальных самок и самцов обнаруженной популяции. Наши данные показывают важность исследования временных водоемов для полной инвентаризации фауны ветвистоусых.

\section{Introduction}

Cladocera is one of the most common groups of microcrustaceans (with diversity comparable to that of Copepoda and Ostracoda), inhabiting various continental water bodies. It is the dominant group in planktonic, benthic and littoral communities [Dumont, 1994; Dumont, Negrea, 2002; Forró et al., 2008; Kotov, 2013]. Today the fauna of cladocerans is intensively studied in different continents, especially in Europe [Alonso, 1996; Hudec, 2000]. Information on the fauna of cladocerans in the European part of Russia is considered to be much more detailed in comparison with Eastern Siberia and Far East [Kotov, 2016; Garibian et al., 2019]. Studies of the cladocerans of European Russia are usually parts of large works devoted to large families: Sididae [Korovchinsky, 2004], Macrothricidae [Smirnov, 1992], Ilyocryptidae [Kotov, Štifter, 2006], Eurycercidae [Kotov, Bekker, 2016]) and Chydoridae [Smirnov, 1971, 1996]. The most complete and updated key for the cladoceran taxa of the Palaearctic was published recently [Rogers et al., 2019].

But still there are several problematic groups with insufficiently developed taxonomy which need to be revised even in European Russia, such as Daphnia O.F. Muller, 1785, Moina Baird, 1850 or Diaphanosoma Fischer, 1850 [Korovchinsky, 2004; Kotov, 2015; Bekker et al., 2016]. One of these groups to be revised is Alona s.lato, an artificial taxon formed as a "store" of convergently similar taxa of the Aloninae with un- 


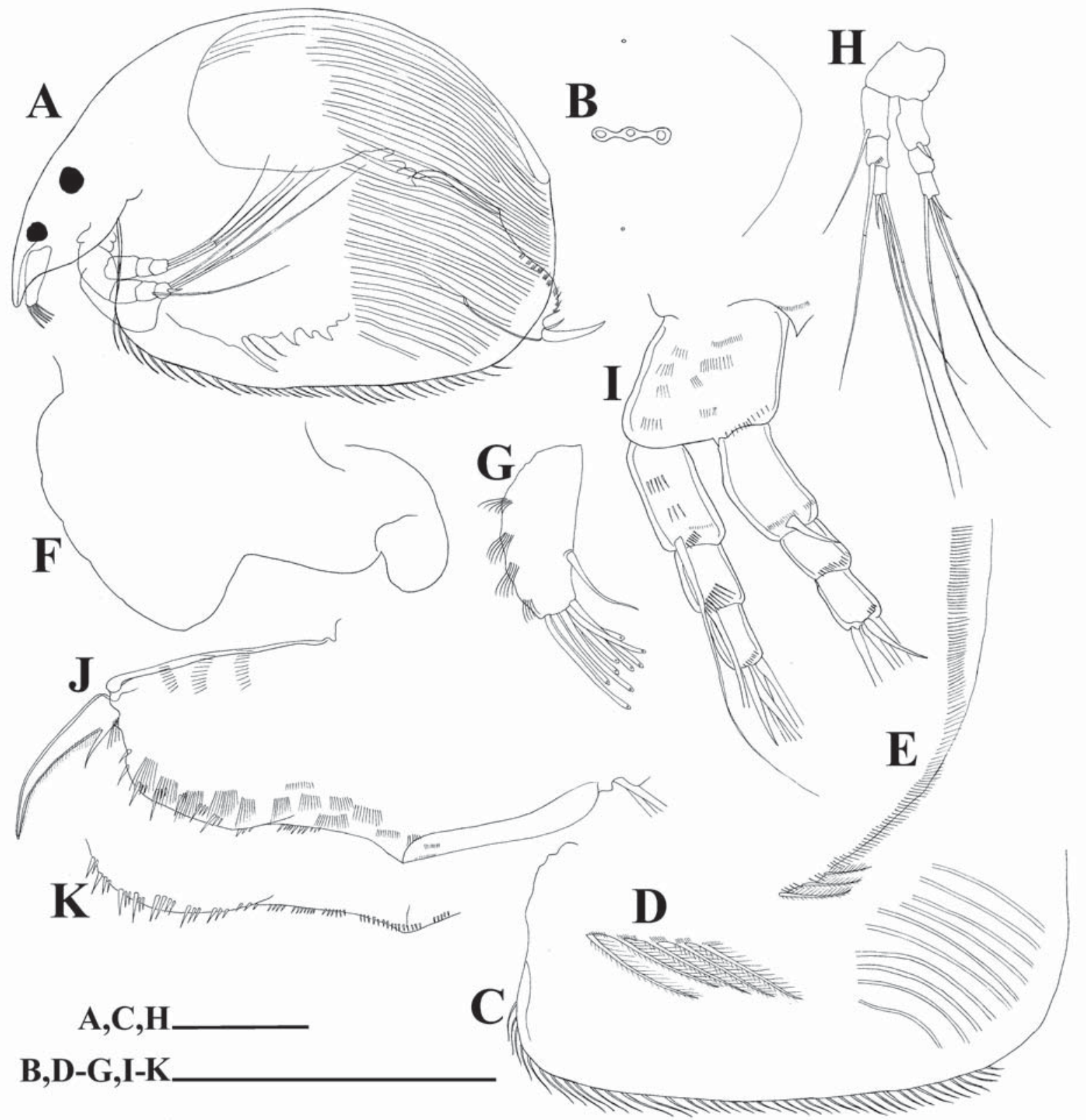

Fig. 1. Coronatella (Ephemeralona) elegans (Kurz, 1875) from roadside ditch near Malye Derbety, Republic of Kalmykia, European Russia, adult parthenogenetic female: A - lateral view, B - head pores, C, D, E - valves armature, F - labrum, G - antenna I, H, I antenna II, J, K - postabdomen. Scale $0.1 \mathrm{~mm}$ (A, C, H), $0.05 \mathrm{~mm}(\mathrm{~B}, \mathrm{D}-\mathrm{G}, \mathrm{I}-\mathrm{K})$.

Рис. 1. Coronatella (Ephemeralona) elegans (Kurz, 1875) из канавы в районе пос. Малые Дербеты, Республики Калмыкия, европейская часть РФ, взрослая партеногенетическая самка: А - вид сбоку, В - головные поры, C, D, E - вооружение створок, F - лябрум, G - антенна I, H, I - антенна II, J, K — постабдомен. Масштаб 0,1 мм (A, C, H), 0,05 мм (B, D-G, I-K).

clear affinities [Van Damme et al., 2010]. Two decades ago, Alona Baird, 1850 was considered as one of the largest genera in Russia, with 13 species found in the country [Sinev, 2002]. Four new species of Alona s.lato were recently described from Russia [Sinev, 1999; Sinev et al., 2009, 2020]. But recently, the generic status of many species-groups of Alona s.lato changed - species of the costata-group, including $A$. costata and A. rustica, were separated into the genus Flavalona Sinev et Dumont, 2016 [Sinev, Dumont, 2016], species of the pulchella-group, including A. karelica were placed into Ovalona Van Damme et Dumont, 2008 [Sinev, 2015], species of the protzi-group, including $A$. protzi and $A$. labroza separated into Phreatalona Van Damme, Brancelj et Dumont, 2009 [Van Damme et al., 2009]. The genus Coronatella Dybowski et Grochowski, 1894 was reestablished for species of the rectangula-group, in- 


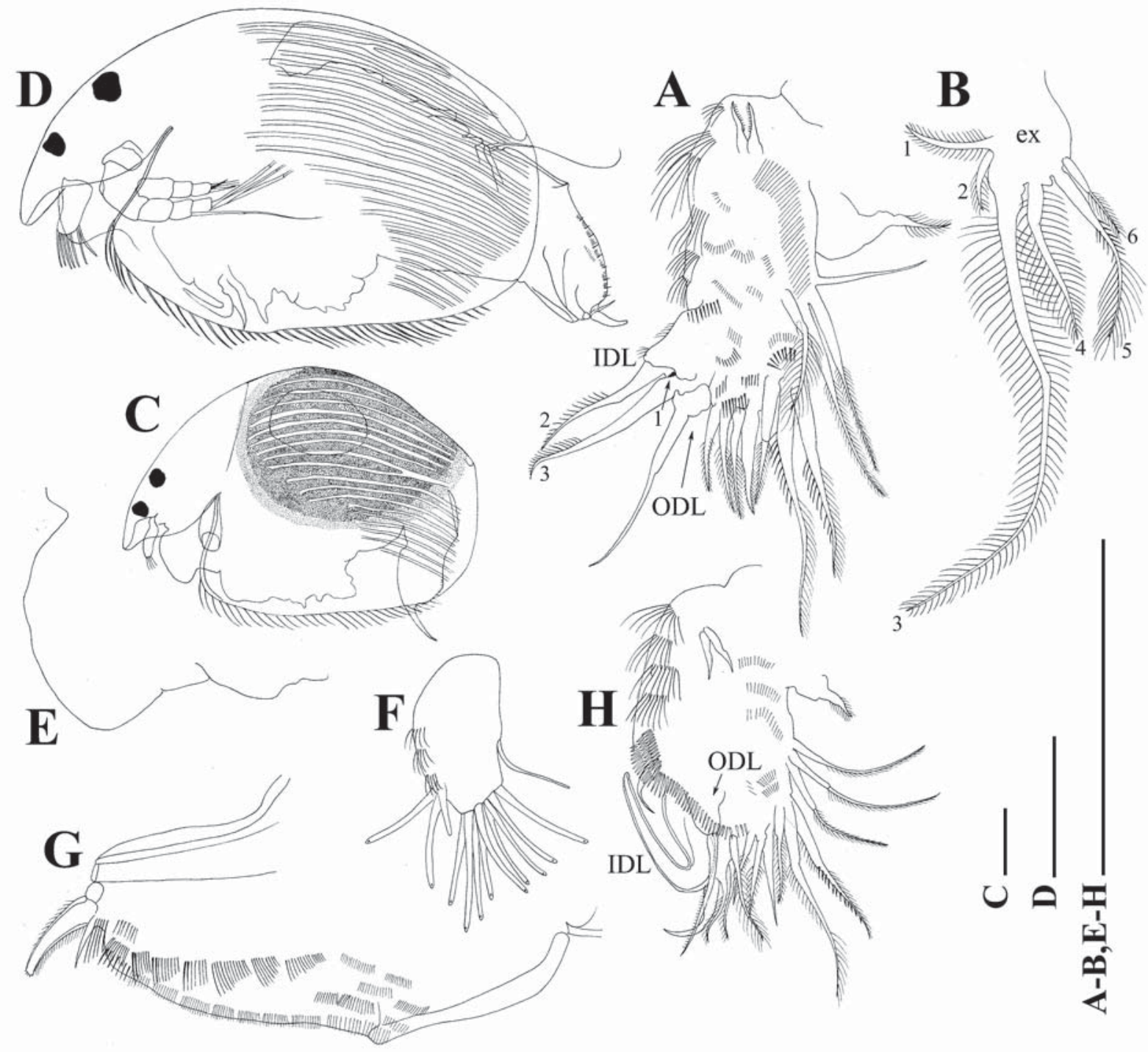

Fig. 2. Coronatella (Ephemeralona) elegans (Kurz, 1875) from from roadside ditch near Malye Derbety, Republic of Kalmykia, European Russia: A, B - adult parthenogenetic female, C - ephippial female, D-H - adult male. A - limb I, B - limb III exopodite, C - lateral view, D - lateral view, E - labrum, F - antenna I, G - postabdomen, H - limb I. Scale $0.1 \mathrm{~mm}(\mathrm{C}, \mathrm{D}), 0.05 \mathrm{~mm}(\mathrm{~A}, \mathrm{~B}, \mathrm{E}-\mathrm{H})$.

Рис. 2. Coronatella (Ephemeralona) elegans (Kurz, 1875) из канавы в районе пос. Малые Дербеты, Республики Калмыкия, европейская часть РФ: А, В - взрослая партеногенетическая самка, С - эфиппиальная самка, D-H - взрослый самец. А торакопод I, В - экзоподит торакопода III, C — вид сбоку, D — вид сбоку, E — лябрум, F — антенна I, G — постабдомен, H торакопод I. Масштаб 0,1 мм (C, D), 0,05 мм (A, B, E-H).

cluding A. rectangula [Van Damme, Dumont, 2008], and recently, species of the elegans-group also were placed within Coronatella as a subgenus, Ephemeralona Sinev, 2020 [Sinev, 2020].

Four representatives of the genus Coronatella were noted from Russia: C. (C.) rectangula (Sars, 1862) is common in both European and Asian Russia [Sinev, 2001], C. (E.) floessneri (Sinev, Alonso et Sheveleva, 2009 ) and $C$. (E.) irinae (Sinev, Alonso et Sheveleva, 2009) are endemics of southern Siberia [Sinev et al., 2009], and East Asian species C. (C.) trachystriata (Chen, Zhang et Liu, 1994) is present in the Amur basin [Kotov et al., 2011; Garybian et al., 2019]. An- alyzing the samples collected in the southern portion of European Russia, we found three remarkable populations of Coronatella (Ephemeralona) belonged to a taxon never reported from Russia before.

\section{Material and methods}

Samples were collected with a small-sized plankton net and fixed in 96\% alcohol. Sample analysis was carried out using an Olympus SZ51 microscope; the material was analyzed on slides (in a drop of glycerine) using an Olympus CX41 microscope with a drawing attachment. 


\section{Results}

Class Branchiopoda Latreille, 1817

Order Anomopoda Sars, 1865

Family Chydoridae Dybowski et Grochowski, 1894

Subfamily Aloninae Dybowski et Grochowski, 1894

Genus Coronatella Dybowski et Grochowski, 1894

Subgenus Coronatella (Ephemeralona) Sinev, 2020

\section{Coronatella (Ephemeralona) elegans (Kurz, 1875)} Figs 1-2.

MATERIAL EXAMINED HERE: 10 parthenogenetic females, ephippial female and adult male from a roadside ditch near Malye Derbety, Republic of Kalmykia $\left(47.97072^{\circ} \mathrm{N}, 44.70483^{\circ} \mathrm{E}\right)$, collected on 3.05.2019 by P.G. Garibian, sample AAK-M-5433; over 200 parthenogenetic females, over 20 ephippial females, over 20 males from a temporary pool at Taman' Penninsula west of Taman' town, Temryuk District, Krasnodar Territory, $\left(45.22278^{\circ} \mathrm{N}\right.$, E $36.68472^{\circ} \mathrm{E}$ ) collected on 6.06 .2009 by Y.R. Galimov, AAK M0972; over 20 parthenogenetic females, 3 ephippial females from a pond at Taman Penninsula west of Taman' town, Temryuk District Krasnodar Territory, $\left(45.2175^{\circ} \mathrm{N}, \mathrm{E} 36.66167^{\circ} \mathrm{E}\right)$ collected in 6.06 2009 by Y.R. Galimov, AAK M-0973. All samples kept in collection of Dr A.A. Kotov, A.N. Severtsov Institute of Ecology and Evolution, Moscow, Russia.

PARTHENOGENETIC FEMALE. Length of adults $0.42-0.52 \mathrm{~mm}$, height $0.29-0.35 \mathrm{~mm}$. Body ovoid in lateral view, compressed laterally, without a medial keel and/or lateral outgrowth, maximum height at middle of body (Fig. 1A). Dorsal margin strongly and regularly convex, posterior margin slightly convex, postero-dorsal and postero-vental angles visibly rounded. Ventral margin almost straight, anterior-ventral angle rounded. Valve sculpture with thick, densely located longitudinal and sometimes anastomizing doubled lines, different modes of valve re-enforcing are characteristic for benthic cladocerans [Kotov, 2006]. Ventral margin (Fig. 1C-E) with numerous setae different in size, shortest one in the middle, postero-ventral angle with numerous setules at inner side of valve margin (Fig. 1E) Head small, with a short rostrum, eye and ocellus welldeveloped, distance between eye and ocellus comparable to distance between ocellus and tip of rostrum. Three connected main head pores (Fig. 1B), PP about 1.7 IP, small lateral head pores located at about IP distance from midline, at the level of middle major head pore. Labrum (Fig. 1F) with a relatively large labral keel with a round apex. Postabdomen (Fig. 1J, K) relatively short and broad, distal part almost straight, dorsal and ventral margin almost parallel in anal portion, ventral portion slightly convex. Preanal margin almost straight, anal margin concave, postanal margin convex. Preanal angle well-defined, postanal angle ill-defined. Postanal margin bearing six or more clusters of simple marginal denticles, decreasing in size proximally. Anal margin with several groups of setules. Lateral side of postabdomen with about 9 fascicles of setules. Antenna I (Fig. 1G) elongated, relatively large, its tip almost reaching tip of rostrum, bearing nine aesthetascs and sensory slender setae. Antenna II (Fig. 1H, I) short, with a robust basipodite and stout branches. Antennal formula: setae $0-0-3 / 1-1-3$, spines $1-0-1 / 0-0-1$. Limb I (Fig. 2A) of moderate size. ODL with a single long minute setulated seta, accessory seta long. IDL with 3 setae, seta 1 reduced, seta 2 and 3 long setulated with thin spinules. Expodite of limb III (Fig. 2B) with 6 setae of different size. Seta 3 the longest one, seta 4 slightly shorter than seta 5 armed with two types of setules in distal portion.
EPHIPPIAL FEMALE. Body slightly higher than parthenogenetic female (Fig. 2C). Ephippium from yellow-brown to dark-brown, covered by prominent longitudinal lines.

MALE. Body oval (Fig. 2D), more elongated than that of parthenogenetic female. labral keel (Fig. 2E) slightly shorter than that of parthenogenetic female. Postabdomen (Fig. 2G) short, slightly narrowing distally in postanal portion. Dorsal distal angle broadly rounded, postanal angle illdefined, preanal angle well defined. Spermoduct opens ventrally at distal end of postabdomen. In place of marginal denticles are located clusters of short setulae, lateral fascicles of setules same as in parthenogenetic female. Postabdominal claw shorter than female, its tip blunt, basal spine long, with cluster of long setulae. Antenna I (Fig. 2F) shorter than in female, with 10 terminal and 2 lateral aesthetascs, male seta arising at 3/4 length from the distal part, about 1/4 of antenna length. Limb I (Fig. 2H) IDL with U-shaped copulatory hook. Copulatory brush seta present. IDL with two seta, seta 2 and 3 slightly shorter than in female, seta 1 is absent, male seta thick and curved.

\section{Discussion}

Morphology of the studied populations fully agrees with the recent redescription of Coronatella (Ephemeralona) elegans [Sinev, 2020]. It clearly differs from two other species of the subgenus found in Russia, south Siberian C. (E.) floessneri (Sinev, Alonso et Sheveleva, 2009) and C. (E.) irinae (Sinev, Alonso et Sheveleva, 2009) in long seta 4 on exopodite III and in male postabdomen with broad postanal portion (see Sinev et al., 2009). C. (E.) elegans inhabits temporary water bodies in Central Europe of Central Europe and Mediterranean [Smirnov, 1971; Bromley, 1993; Alonso, 1996, Flössner, 2000; Ghaouaci et al., 2018; Sinev, 2020], its easternmost record from Europe is from Slovenia [Hudec, 2010], at about 1400 km from Taman' peninsula and $2000 \mathrm{~km}$ from Kalmykia. Our data suggest that the species can be present in the vast arid area along the north coast of the Black Sea - South Ukraine and the southern part of European Russia. Sars [1903] reported C. (E.) cf. elegans (as Alona elegans) from water bodies in Akmolinsk (now Nur-Sultan), Kazakhstan, but his drawings and description are not detailed enough to confirm population identity with $C$. (E.) elegans s.str. [Sinev, 2020]. Species inhabiting temporary waters frequently remain undiscovered, as the main attention of hydrobiologists is focused on economically important rivers and permanent lakes.

Our data demonstrate the importance of sampling in temporary waterbodies for full evaluation of local Cladocera fauna, especially in arid areas. Cladocera of the South European part of Russia, especially in steppe regions, are far from fully studied.

Acknowledgements. We are deeply grateful to Dr. Alexey A. Kotov for valuable critique and to Dr. Russell Shiel for the linguistic corrections. The study is supported by the Russian Foundation for Basic Research (grant 20-04-00181). 


\section{References}

Alonso M. 1996. Crustacea, Branchiopoda // Fauna Iberica. Madrid. Museo Nacional de Ciencias Naturales. Consejo Superior de Investigationes Científicas. Vol.7. 486 p.

Bekker E.I., Karabanov D.P., Galimov Y.R., Kotov A.A., 2016. DNA barcoding reveals high cryptic diversity in the North Eurasian Moina species (Crustacea: Cladocera) // PLoS ONE. Vol.11. No.8. P.1-19. https://doi.org/10.1371/journal.pone. 0161737

Bromley H.J. 1993. A checklist of the Cladocera of Israel and Eastern Sinai // Hydrobiologia. Vol.257. No.1. P.21-28. https: //doi.org/10.1007/BF00013993

Dumont H.J., Negrea S.V. 2002. Introduction to the class Branchiopoda // Dumont H.J. Guides to the identification of the microinvertebrates of the continental waters of the world. 19. Leiden. Backhuys Publishers. 398 p.

Dumont H.J. 1994. On the diversity of the Cladocera in the tropics // Hydrobiologia. Vol.272. No.1-3. P.27-38.

Flössner D. 2000. Die Haplopoda und Cladocera (ohne Bosminidae) Mitteleuropas. Leiden. Backhuys Publishers. 428 S.

Forró L., Korovchinsky N.M., Kotov A.A., Petrusek A. 2008. Global diversity of cladocerans (Cladocera; Crustacea) in freshwater // Hydrobiologia. Vol.595. P.177-184. https://doi.org/ 10.1007/978-1-4020-8259-7 19

Garibian P.G., Chertoprud E.S., Sinev A.Y., Korovchinsky N.M., Kotov A.A. 2019. Cladocera and Copepoda (Crustacea: Branchiopoda) of the Lake Bolon and its basin (Far East of Russia) // Arthropoda Selecta. Vol.28. No.1. P.37-63. https://doi.org/ 10.15298/arthsel.28.1.05

Ghaouaci S., Amarouayache M., Sinev A.Y., Korovchinsky N.M., Kotov A.A. 2018. An annotated checklist of the Algerian Cladocera (Crustacea: Branchiopoda) // Zootaxa. Vol.4377. No.3. P.412-430. https://doi.org/10.11646/zootaxa.4377.3.5

Hudec I. 2010. [Fauna Slovenska III. Anomopoda, Ctenopoda, Haplopoda, Onychopoda (Crustacea: Branchiopoda)]. Bratislava: Veda. 496 p. [In Czech]

Korovchinsky N.M. 2004. [Cladocerans of the order Ctenopoda of the world fauna (morphology, systematics, ecology, biogeography)]. Moscow: KMK Sci. Press. 410 p. [In Russian]

Kotov A.A. 2013. [Morphology and phylogeny of the Anomopoda (Crustacea: Cladocera)]. Moscow: KMK Sci. Press. 638 p. [In Russian]

Kotov A.A. 2006. Adaptations of the Anomopoda (Cladocera) for benthic mode of life // Zoologicheskiy Zhurnal. Vol.85. P.10431059 .

Kotov A.A. 2015. A critical review of the current taxonomy of the genus Daphnia O. F. Müller, 1785 // Zootaxa. Vol.3911. No.2. P.184-200.

Kotov A.A. 2016. [Faunistic complexes of the Cladocera (Crustacea, Branchiopoda) of Eastern Siberia and Far East of Russia] // Zoologicheskiy Zhurnal. Vol.95. No.7. P.748-768 [in Russian].

Kotov A.A., Bekker E.I. 2016. Cladocera: Family Eurycercidae (Branchiopoda: Cladocera: Anomopoda) // Dumont H.J. Indentification guides to the Plankton and Benthos of inland waters. 25. Weikersheim. Backhuys Publishers. 89 pp.

Kotov A.A., Śtifter P. 2006. Cladocera: family Ilyocryptidae (Branchiopoda: Cladocera: Anomopoda) // Guides to the identification of the microinvertebrates of the Continental Waters of the world. Hague. Academic Publishing. 172 pp.

Kotov A.A., Sinev A.Yu., Korovchinsky N.M., Smirnov N.N., Bekker E.I., Sheveleva N.G. 2011. [Cladocera (Crustacea,
Branchiopoda) of the Zeya basin (Amurskaya Area, Russian Federation). 1. New taxa for fauna of Russia] // Zoologichesky Zhurnal. Vol.90. No.2. P.131-142 [in Russian].

Rogers D.C., Kotov A.A., Sinev A.Y., Glagolev S.M., Korovchinsky N.M., Smirnov N.N., Bekker E.I. 2019. Chapter 16.2. Arthropoda: Class Branchiopoda // Thorp and Covich's Freshwater Invertebrates Volume IV. Academic press. P.643-724.

Sinev A.Yu. 1999. Alona werestschagini sp.n., new species of genus Alona Baird, 1843, related to A. guttata Sars, 1862 (Anomopoda, Chydoridae). // Arthropoda Selecta. Vol.8. No.1. P. 23-30.

Sinev A.Yu. 2001. Distribution and polymorphism of Alona rectangula Sars, 1862 (Branchiopoda: Cladocera: Anomopoda) in Russia and surrounding countries // Arthropoda Selecta. Vol.10. No.2. P.83-86.

Sinev A.Yu. 2002. [A key to identifying cladocerans of the genus Alona (Anomopoda, Chidoridae) from the Russian European part and Siberia] // Zoologichesky Zhurnal. Vol.81. No.8. P.926-939 [in Russian].

Sinev A.Y. 2015. Revision of the pulchella-group of Alona s. lato leads to its translocation to Ovalona Van Damme et Dumont, 2008 (Branchiopoda: Anomopoda: Chydoridae) // Zootaxa. Vol.4044. No.4. P.451-492.

Sinev A.Y. 2020. Revision of the elegans-group of Alona s. lato and its status as a subgenus of Coronatella Dybowski \& Grochowski, 1894 (Cladocera: Anomopoda: Chydoridae) // Zootaxa. Vol.4732. No.4. P.501-526.

Sinev A.Y., Alonso M., Sheveleva N.G. 2009. New species of Alona from South-East Russia and Mongolia related to Alona salina Alonso, 1996 (Cladocera: Anomopoda: Chydoridae) // Zootaxa. Vol.2326. P.1-23.

Sinev A.Y., Dumont H.G. 2016 Revision of the costata-group of Alona s. lato (Cladocera:Anomopoda: Chydoridae) confirms its generic status // European Journal of Taxonomy. Vol.223. P. $1-38$.

Sinev A.Y., Karabanov D.P., Kotov A.A., 2020. A new North Eurasian species of the Alona affinis complex (Cladocera: Chydoridae) // Zootaxa. Vol.4767. No.1. P.115-137.

Smirnov N.N. 1971. [Chydoridae of the world fauna] // Fauna SSSR. Rakoobraznie. Vol.1. Vyp.2. 531 p. [In Russian]

Smirnov N.N. 1992. The Macrothricidae of the world // Guides to the identification of the microinvertebrates of the Continental Waters of the world. The Hague: SPB Academic Publishing. $143 \mathrm{pp}$.

Smirnov N.N. 1996. Cladocera: the Chydorinae and Sayciinae (Chydoridae) of the world // Guides to the identification of the microivertebrates of the Continental Waters of the world. Amsterdam: SPB Academic Publishing. 197 pp.

Van Damme K., Brancelj A., Dumont H.J. 2009. Adaptations to the hyporheic in Aloninae (Crustacea: Cladocera): allocation of Alona protzi Hartwig, 1900 and related species to Phreatalona gen. nov. // Hydrobiologia. Vol.618. P.1-34.

Van Damme K., Dumont H.J. 2008. Further division of Alona Baird, 1843: separation and position of Coronatella Dybowski \& Grochowski and Ovalona gen.n. (Crustacea: Cladocera) // Zootaxa. Vol.1960. P.1-44.

Van Damme K., Kotov A.A., Dumont H.J. 2010. A checklist of names in Alona Baird 1843 (Crustacea: Cladocera: Chydoridae) and their current status: an analysis of the taxonomy of a lump genus // Zootaxa. Vol.2330. P.1-63.

Responsible editor K.G. Mikhailov 